DOI: https://doi.org/10.11144/Javeriana.upsy18-3.crsb

\title{
A Comparative Research of Sexual Behaviour and Risk Perception in Two Cohorts of Spanish University Students*
}

\section{Un estudio comparativo de la conducta sexual y la percepción de riesgo en dos cohortes de estudiantes universitarios españoles}

Received: 14 July 2014 | Accepted: 21 May 2019

\author{
YOLANDA PASTOR ${ }^{\mathrm{a}}$ \\ King Juan Carlos University, Spain \\ ORCID: http://orcid.org/0000-0003-0667-958X \\ Carolina Rojas-Murcia \\ Private practice, Spain \\ ORCID: http://orcid.org/0000-0002-0645-2142
}

a Correspondence author. Email: yolanda.pastor@urjc.es

How to cite: Pastor, Y., \& Rojas-Murcia C. (2019). A comparative research of sexual behaviour and risk perception in two cohorts of Spanish university students. Universitas Psychologica, 18(3),

1-14. https://doi.org/10.11144/Javeriana.upsy18-3.crsb

\section{ABSTRACT}

The aim of this research was to describe the sexual behaviour and HIV/ AIDS risk perception in two cohorts of Spanish university students. A cross-sectional design of two cohorts was employed. A total of 230 university students in $2004\left(\mathrm{M}_{\mathrm{age}}=19.77 ; \mathrm{SD}=1.73 ; 72.6 \%\right.$ females $)$ and 264 in $2012\left(\mathrm{M}_{\mathrm{age}}=19.47 ; \mathrm{SD}=1.73 ; 73.5 \%\right.$ females $)$ were recruited. A self-developed questionnaire on sexual behaviour was administered. A MANOVA per cohort, gender and age was performed. The results revealed that there were no differences between the cohorts regarding sexual practices. About one-fifth of sexually active young people used condoms regularly but not always, around one-sixth sometimes or never used them, half of the respondents did not usually require their sexual partners to take an HIV test and only the ten percent had ever undergone it. Three quarters of the subjects perceived some degree of invulnerability to HIV/AIDS. Spanish females perceived themselves more invulnerable. Keywords university students; sexual behaviour; risk perception; HIV/AIDS prevention; cohorts.

\section{RESUMEN}

El objetivo de esta investigación fue describir el comportamiento sexual y la percepción del riesgo ante el VIH/SIDA en dos cohortes de estudiantes universitarios españoles. Se empleó un diseño transversal de dos cohortes. Se reclutaron un total de 230 estudiantes universitarios en $2004\left(M_{\text {edad }}=19,77 ; \mathrm{dt}=1,73 ; 72,6 \%\right.$ mujeres $)$ y 264 en 2012 $\left(\mathrm{M}_{\text {edad }}=19,47 ; \mathrm{dt}=1,73 ; 73,5 \%\right.$ mujeres $)$. Se administró un cuestionario de elaboración propia sobre el comportamiento sexual. Se realizó un MANOVA por cohorte, sexo y edad. Los resultados revelaron que no había diferencias entre las cohortes con respecto a las prácticas sexuales. Aproximadamente una quinta parte de los jóvenes sexualmente activos utilizaban preservativos con regularidad pero no siempre, alrededor de una sexta parte a veces o nunca los utilizaban, la mitad de los encuestados no solían exigir a sus parejas sexuales que se sometieran a una prueba de detección del VIH y tan sólo el 10\% se la había realizado alguna vez. Tres cuartas partes de los sujetos percibieron algún 
grado de invulnerabilidad ante el VIH/SIDA. Las mujeres españolas se consideraban más invulnerables.

Palabras clave

estudiantes universitarios; conducta sexual; percepción de riesgo; prevención del VIH/SIDA; cohortes.

According to the World Health Organization (WHO), in 2014, around 37 million people lived with HIV in the world. Younger populations appeared as especially vulnerable to the disease. WHO reported that around $40 \%$ of all new infections in 2009 were young people between 15 and 24 years of age. Data from the Division of HIV/AIDS Prevention also reported that 38\% of all new HIV cases diagnosed in 2016 in the United States were young people aged from 13 to 24. Furthermore, it was estimated that around $51 \%$ of young people with HIV between 13 and 24 years of age were unaware of this situation by 2016 in USA (Centers for Disease Control and Prevention, 2017). In Spain, around 10\% of all new infections in 2017 were in young people between 20 and 24, sexual transmission being the most common way of contracting the disease (82.5\%, 28.2\% heterosexual relationships and $54.3 \%$ homosexual relationships). In addition, $47.8 \%$ of Spanish people diagnosed with HIV in 2017 had a late diagnosis. This implies a high risk of transmission of the virus due to lack of knowledge (HIV Surveillance and Risk Behaviour Area, 2018).

The sexual behaviour of young people therefore constitutes a major risk factor in contracting HIV/AIDS and other sexually transmitted diseases. Inconsistent use of condoms, a high number of different sexual partners, having sex after drinking alcohol and the low frequency of HIV testing are the most frequent risk behaviours reported in international research (Castro \& SantosIglesias, 2016; Cortés Alfaro, García Roche, \& Ochoa Soto, 2015; Fernández-Silva \& SánchezMartínez, 2018; Folasayo et al., 2017; Xu et al., 2019; Mavhandu-Mudzusi \& Asgedom, 2016; Othieno, Okoth, Peltzer, Pengpid \& Malla, 2015; Thomas, Yarandi, Dalmida, Frados \& Klienert, 2015). Previous studies showed that Spanish young people do not use condoms consistently (Bagmato, Jenaro, Flores \& Guzmán, 2014; Ballester, Gil, Jiménez \& Ruiz, 2009; Castro $\&$ Santos-Iglesias, 2016). The data showed that condoms were used in 3 out of 4 sexual encounters (Bagmato et al., 2014). In a study of the use of condoms in different sexual practices, Ballester et al. (2009) found that young people only used them in $53 \%$ of coital relations in the previous month, $3 \%$ for oral intercourse and $13 \%$ for anal intercourse, practices engaged by a large number of subjects ( $73 \%$ performed oral and $16 \%$ anal intercourse). In this study, there were few young people who have ever asked their partner to be tested for HIV (14\%) and also very few have ever been tested (40\%) (Ballester et al., 2009).

With a sample of 1,428 Spanish subjects between 14 and 24 years of age, Failde, Lameiras and Bimbela (2008) found that young people used condoms less frequently in oral and coital sex than teenagers. They also found that boys have more sexual partners than girls, but also use condoms more frequently (Failde et al., 2008). Whereas European university students admitted to have had an average of two sexual partners throughout their lives (Calatrava, López-Del Burgo \& de Irala, 2012), in a study in Spain this figure increased to an average of 4.5 partners (Serrano et al., 2005).

Likewise, a European review showed that young people become sexually active at an increasingly earlier age, have favourable attitudes toward casual sex, become unaware of the risks of serial monogamy and have misconceptions about effective measures to prevent HIV/ AIDS (Calatrava et al., 2012). This fact, along with the natural characteristics of the psychosocial development of these ages, such as the underestimation of health risks, justifies the need to study this group in an attempt to eradicate HIV (Larrañaga, Yubero \& Yubero, 2012).

This task is especially difficult when we compare the underestimation of perceived risk with the instant benefits that sexual relations provide (ONUSIDA, 2012). One of the most important factors that intervene in the decrease of the motivation to perform safe sex is the low 
perceived risk (Chávez, Petrzelová \& Zapata, 2009; Sánchez, Rubio, Páez \& Blanco, 1998) which is explained by a cognitive bias called unrealistic optimism (Sánchez et al., 1998, p. 7).

In 1980, psychologist Neil D. Weinstein described the existence of a cognitive bias which produces the unconscious belief that one has less probability than peers of undergoing negative events (Ubillos, Páez, Mayordomo, \& Sánchez, 2003, p. 262; Weinstein, 1980, p. 806). This bias is referred to as unrealistic optimism when it describes positive events, whereas when it regards negative situations, it receives the name of illusion of invulnerability (Sánchez et al., 1998, p. 8).

Research from around the world reported that young people generally considered themselves unlikely to contract HIV/AIDS (Amare, Yeneabat \& Amare, 2019; Haile, Kingori, Darlington, Basta \& Chavan, 2017; Olubola, 2015). A study conducted in the Spanish context reported that $61 \%$ of first year university students in Barcelona considered that their possibilities of infection were lower than average (Planes, 1993; quoted in Planes et al., 2005). Ubillos et al. (2003) also found that $75 \%$ of Spanish university students perceived themselves as less vulnerable to the disease and $84 \%$ thought that most people assume the same risk in sexual relations as themselves (false consensus bias). In a review paper, Planes et al. (2005) reported that the young university students' perception of risk of contracting HIV/AIDS was declining over time, being much more pronounced in situations of serial monogamy, as compared to casual relations. In a more recent study of Spanish university students, $65 \%$ perceived themselves to be at a lower risk than their colleagues of contracting HIV/AIDS (Pastor, MartínezZaragoza, Benavides, Solanes \& Martín, 2008). In 2012, almost $72 \%$ of Spanish university students perceived themselves as invulnerable to some degree (Rojas-Murcia, Pastor \& EstebanHernández, 2015).

In a research study on the perceived risk of heterosexual transmission of HIV by Spanish university students with two cohorts between 1996/97 and 2000/01, researchers concluded that perceived risk remained stable in both sexes during the studied period and was significantly lower when participants were in an affective relationship in both cohorts (Lameiras, Rodríguez \& Dafonte, 2002).

Teague (2009) also carried out research on two cohorts to analyse college students' perceptions of their vulnerability to HIV, between 1990 and 2005 in the USA. The results proved that 1990 respondents saw themselves as less vulnerable to HIV/AIDS than others, a pattern which was repeated amongst 2005 respondents, even though many in both cohorts were involved in objectively risky practices. To compare the risk behaviour of both cohorts, it was observed that the rate of sexually active students had decreased in 2005 and the frequency of condom use had increased.

Given the still high incidence of HIV/AIDS among young people and the absence of changes in the perception of risk over time in previous studies in our country, it is useful to study how sexual behaviour and the associated perception of risk has evolved in recent years. This research is therefore aimed at describing the sexual behaviour and risk perception of two cohorts of Spanish university students in 2004 and 2012.

The hypotheses that have guided this investigation have been:

Hypothesis 1. Given the period of time analyzed and the absence of generalized preventive programs in the Spanish context, risk perception of contracting HIV/AIDS and sexual behaviour would remain stable in the two cohorts studied.

Hypothesis 2. Female university students would have a lower perceived risk of contracting HIV/AIDS, a smaller number of sexual partners and use condoms less frequently than male.

Hypothesis 3. As they are university students, it could be hypothesized that at an older age there would be greater awareness of the risk of HIV/ AIDS and greater sexual protection behaviours, although these differences would be small.

Hypothesis 4. Young people with stable partners would have a greater illusion of invulnerability to HIV/AIDS, would probably use fewer condoms, would have fewer sexual partners throughout their lives, and would talk more 
with their partners about HIV/AIDS than those without stable partners.

\section{Method}

\section{Design and Participants}

A cross-sectional design with two cohorts was used. The sample was selected using a convenient sampling method for both cohorts, choosing courses whose teachers agreed to pass the questionnaire round during their teaching hours in the second semester.

Since it was a large study, sample size determination was based on the prevalence of the illusion of invulnerability $(76 \%)$ reported in previous studies (Ubillos et al. 2003, p. 261) with an accuracy of $5 \%$ and confidence level of $95 \%$. This involved using a sample of 289 subjects.

The subjects were 494 volunteer respondents from Spanish universities in Madrid and the Community of Valencia. They were selected for convenience by non-probabilistic sampling accessibility. The sample was comprised of 230 students in 2004 and 264 in 2012, with an average age of $19.77(\mathrm{SD}=1.73$; Range $=$ 17-24) in the first cohort and 19.47 (SD = 1.73; Range $=18-24)$ in the second. In both cohorts, the percentage of females was of $73.5 \%(n=169$ in 2004; $\mathrm{n}=194$ in 2012), whereas only $26.5 \%$ $(\mathrm{n}=61$ in $2004 ; \mathrm{n}=70$ in 2012) of the subjects were males.

With regard to the comparability of the cohorts based on demographic variables, no significant differences were found in age group $(\mathrm{c} 2(3,493)=4.025 ; p=0.25)$, or sex $(\mathrm{c} 2(1$, 492) $=0.048 ; p=0.82)$.

\section{Variables and Instruments}

The variables considered in this study were social-demographic characteristics, sexual behaviour and the illusion of invulnerability.

The social-demographic variables of age, gender and sexual orientation were evaluated using closed questions in a self-prepared questionnaire. Four age groups were formed for comparative analyses $(\mathrm{G} 1=17-18 ; \mathrm{G} 2=19-20$; $\mathrm{G} 3=21-22$ and $\mathrm{G} 4=23-24)$.

Sexual behaviour was measured by asking the subjects about the frequency of their sexual relations in the last year (1), how often they used condoms (2), the number of different sexual partners (3), time in a stable relationship (4), frequency of safe sex communications with partners (5) and the frequency of asking their partners to take the HIV test (6); in all cases using closed questions. All of them were assessed using a 4-point response scale. To question one, the response scale was sporadically $(1=$ less than 5 times a year), almost every month $(2=$ from 6 to 11 times), monthly ( $3=$ more than 12 times) and weekly ( $4=$ every week). The answer scale used in the questions two, five and six were never (1), sometimes (2), usually (3) and always (4). To question three, the response scale was between one and two (1), between three and four (2), between five and six (3) and more than six (4). To question four, the response scale was less than six months (1), six months to one year (2), between one and two years (3) and more than two years (4). Other variables studied were whether they currently have a stable relationship, whether they have had a sexually transmitted disease, if they have ever taken the HIV test and if they use condoms in a situation of infidelity. The scale of response of these last variables was dichotomic (yes or no).

The illusion of invulnerability was assessed by means of an indirect method consisting of a combination of two questions: on the one hand, the researchers asked about the perceived risk of people with similar age and gender contracting HIV and, on the other, about the self-perceived risk. The response scale to these questions ranged from 0 (totally improbable) to 100 (totally probable), divided into intervals of 10. The illusion of invulnerability was calculated by subtracting the perceived risk of other people from the self-perceived risk of contracting the disease, only amongst sexually active students (as, otherwise, the bias would be meaningless). A null or negative difference would indicate that the students saw themselves more vulnerable to 
infection than their peers (absence of the illusion of invulnerability), whereas a positive difference would indicate less probability of becoming infected (presence of illusion of invulnerability). This evaluation method was created by Burger and Burns (1988) with the aim of reducing social desirability in responding.

To study the illusion of invulnerability, the scores were grouped into four categories:

$-1=$ score $\leq 0=$ indicates the absence of the illusion of invulnerability

$-2=$ score $10=$ indicates a low illusion of invulnerability

$-3=$ score $20=$ indicates medium illusion of invulnerability

$-4=$ score $\geq 30=$ indicates high illusion of invulnerability

To guarantee comprehension, the complete questionnaire was previously administered to a small sample of 15 college students, who in turn were interviewed about the difficulties encountered in answering. No difficulties in understanding the items were reported.

\section{Procedure}

A descriptive and cross-sectional study was carried out.

The collection of information procedure was positively evaluated by the Ethics Committee of our university before the research began. The researchers developed a self-prepared questionnaire, which was administered to a number of university students in class time, after asking permission from the teachers. Students who wished to participate previously signed an informed consent form. The questionnaires were answered voluntarily and anonymously. The researchers in charge of distributing the surveys did not know any of the students involved, to prevent influence in the decision to answer and the answer itself. These conditions were essential requirements for the approval of the university authorities to do the research.

\section{Data Analysis}

To study statistically significant differences in sexual activity a MANOVA analysis per cohort, gender and age was performed with scaled dependent variables (see variables description). It was considered important to perform a multivariate analysis of variance to obtain a robust statistic insensitive to slight deviations from the parametric assumptions, mainly of multivariate normality and homoscedasticity (Bisquerra, 1989, p. 142) and to reduce the Type I error. The MANOVA analysis was only performed when the subjects claimed to be sexually active.

In addition, a descriptive analysis of the variables of sexual activity according to cohort and gender was carried out. Again, these analyses were only carried out on sexually active subjects. With dichotomic variables (see variables description above), Pearson's Chi squared was performed to study group differences as per sex or cohort, when the conditions of applications were met, otherwise an equivalent non-parametric test (such as the Mann Whitney U test) was used. Another independent variable used to study group differences was whether or not the subject was in a stable relationship. The statistical tests mentioned above also were carried out using this independent variable.

To perform the above-mentioned analyses, SPSS 20.0 was used.

\section{Results}

The MANOVA analysis (cohort $\mathrm{x}$ gender $\mathrm{x}$ age group) performed on the sexual behaviour variables with sexually active young people detected the existence of significant main effects per gender (Wilks $=0.943 ; \mathrm{F}(6,371)=$ 3.729; $\left.p=0.001 ; \eta^{2}=0.057\right)$ but not per age group $($ Wilks $=0.937 ; \mathrm{F}(18,1049)=$ $1.365 ; p=0.133$ ), nor cohort (Wilks $=0.98$ F $(6,371) ;=1.145 ; \mathrm{p}=0.336)$, nor per any interaction effect between independent variables. Since no differences by age appeared and it lacked descriptive value, there is no 
additional information on this point (hypothesis 3 ) in the results section.

The descriptive statistics of the different variables studied can be seen in table 1 .

Table 1

Descriptive statistics

\begin{tabular}{|c|c|c|c|c|c|c|}
\hline Descriptive & $\begin{array}{c}\text { Cohort } \\
2004\end{array}$ & $\begin{array}{c}\text { Cohort } \\
2012\end{array}$ & Males & Females & $\begin{array}{c}\text { Stable } \\
\text { partner }\end{array}$ & $\begin{array}{c}\text { Not stable } \\
\text { partner }\end{array}$ \\
\hline $\begin{array}{l}\text { Frequency of sexual } \\
\text { relationships } \\
(\text { scale } 1-4)^{1}\end{array}$ & $2.91(1.18)$ & $2.81(1.18)$ & $2.42(1.26)$ & $3.04(1.09)$ & $3.50(0.77)$ & $1.91(1.04)$ \\
\hline $\begin{array}{l}\text { Frequency in the use of } \\
\text { condoms } \\
\text { (scale 1-4) }\end{array}$ & $3.46(0.91)$ & $3.44(0.95)$ & $3.64(0.70)$ & $3.36(1.01)$ & $3.27(1.07)$ & $3.71(0.60)$ \\
\hline $\begin{array}{l}\text { Number of sexual partners } \\
(\text { scale 1-4) }\end{array}$ & $1.54(0.90)$ & $1.62(0.98)$ & $1.77(1.05)$ & $1.50(0.89)$ & $1.45(0.85)$ & $1.77(1.06)$ \\
\hline $\begin{array}{l}\text { Stable relationship (scale: } \\
\text { YES, NO) }\end{array}$ & $111(59.4)$ & $130(58)$ & $51(42.5)$ & $190(65.3)$ & & \\
\hline $\begin{array}{l}\text { Time in stable relationship } \\
\text { (scale 1-4) }\end{array}$ & $3.03(1.0)$ & $3.17(1.02)$ & $2.95(1.09)$ & $3.15(0.98)$ & $3.14(0.98)$ & $1.83(1.32)$ \\
\hline $\begin{array}{l}\text { Frequency of safe sex } \\
\text { communication (scale 1-4) }\end{array}$ & $2.95(0.88)$ & $2.88(0.88)$ & $2.79(0.84)$ & $2.97(0.89)$ & $3.0(0.89)$ & $2.8(0.85)$ \\
\hline $\begin{array}{l}\text { Illusion of invulnerability } \\
\text { (scale 1-4) } \\
\text { Have had a sexual }\end{array}$ & $2.25(1.18)$ & $2.38(1.15)$ & $1.96(1.06)$ & $2.47(1.17)$ & $2.45(1.18)$ & $2.16(1.13)$ \\
\hline $\begin{array}{l}\text { transmission disease (scale: } \\
\text { YES,NO) }^{2}\end{array}$ & $4(2.1)$ & $10(4.5)$ & $1(0.8)$ & $13(4.5)$ & $8(3.3)$ & $6(3.6)$ \\
\hline $\begin{array}{l}\text { Have the HIV test conducted } \\
\text { (scale: YES,NO) }{ }^{2} \\
\text { To ask their partner to do the }\end{array}$ & $10(5.3)$ & $20(8.9)$ & (9.1) & $9(6.5)$ & $20(8.3)$ & $10(5.9)$ \\
\hline $\begin{array}{l}\text { HIV test } \\
\text { (scale: } 1-4)^{1}\end{array}$ & $1.53(0.59)$ & $1.59(0.67)$ & $1.56(0.67)$ & $1.57(0.62)$ & $1.50(0.62)$ & $1.65(0.66)$ \\
\hline $\begin{array}{l}\text { Use of condoms for } \\
\text { infidelity } \\
\text { (scale: } \mathrm{YES}, \mathrm{NO})^{2}\end{array}$ & $185(97.9)$ & $223(99.6)$ & $119(98.3)$ & $289(99)$ & $237(98.3)$ & $169(99.4)$ \\
\hline
\end{tabular}

Differential and descriptive analysis by cohort (hypothesis 1)

The vast majority of the participants in both cohorts reported being heterosexual $(92.5 \%$ and $90.5 \%$ in cohort 1 and 2 respectively). No significant differences were found per cohort $\left(\chi^{2}\right.$ $(2,491)=4.480 ; p=0.106)$.

About half of the young people in both groups reported having a stable partner (almost 52\% in cohort 1 and $50 \%$ in cohort 2). Again, no significant differences were found per cohort $\left(\chi^{2}\right.$ $(2,492)=1.352 ; p=0.509)$. In cohort $1,35 \%$ of respondents stated that their relationship lasted between 1 and 2 years and $40 \%$ stated that it lasted more than 2 years. Similar results were found in cohort $2\left(\chi^{2}(3,257)=4.557 ; p=\right.$ $0.207), 43 \%$ reporting to have a relationship that lasted between 1 and 2 years and 50\% stated that it lasted more than 2 years.

Almost all young people stated that they maintained relations with caresses and fondling (95\% and 92\% in cohort 1 and 2 respectively; $\left.\chi^{2}(1,491)=1.386 ; p=0.239\right)$. Most of the participants in both cohorts reported being sexually active (oral sex or penetration). In the 2004 sample, $83 \%$ of the subjects declared having experienced oral sex or sexual intercourse at least once and a very similar number $(85 \%)$ in the 2012 cohort stated to be sexually active. No significant differences between both cohorts were found in the number of sexually active young people $\left(\chi^{2}(1,491)=0.231 ; p=0.63\right)$. All the results presented below refer to sexually active young people.

We then examined the characteristics of sexual behaviour per cohort, the differences between cohorts being insignificant. In cohort 1 , only $45 \%$ of males stated that they had a lower risk of contracting HIV/AIDS than other people similar to them and $72 \%$ of females perceived themselves with less risk. Whereas 9\% of males presented a higher degree of perceived invulnerability in this cohort, $31 \%$ of females in the group reported high invulnerability. In cohort 2, whereas $65 \%$ of males presented some degree of the illusion of invulnerability, the figure in females was almost $72 \%$. Eighteen percent and $28 \%$ of males and females respectively in this group showed high perceived invulnerability. In this case, the comparison of the males of both cohorts indicated that there were significant differences in perceived invulnerability (MannWhitney $U=1398.5, Z=-2.06, p=0.039$ ), the invulnerability perception being greater in males belonging to cohort 2 (see Figure 1). 
Figure 1

Illusion of invulnerability to HIV/AIDS by cohort and gender

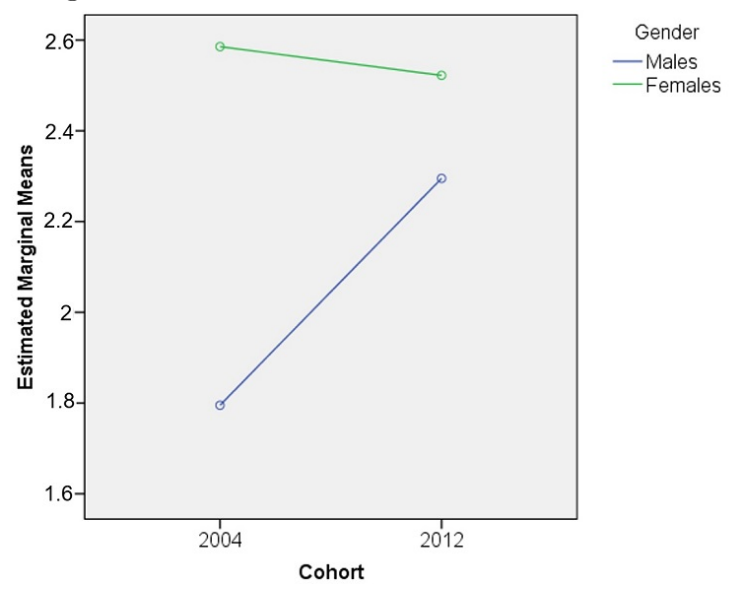

Regarding the frequency of sexual relations, $45 \%$ reported having sex every week and $23 \%$ every month in cohort 1 . A similar rate was observed in cohort 2, 39\% every week and 25\% every month. Sixty-eight percent of young people reported having sex with 1 or 2 different partners throughout their life, $18 \%$ with $3-4$ people and $15 \%$ with 5 or more in cohort 1 . Similar rates were reported in cohort 2. Sixty-five percent reported having had 1 or 2 sexual partners, 19\% had $3-4$ and $16 \%$ had 5 or more.

With respect to the use of condoms, nearly $70 \%$ of the young people reported using them always and around $17 \%$ regularly in both groups. However, the majority of both groups (around 99\%) stated that they used condoms in infidelity. Nearly $65 \%$ of the young people stated talking to their partner about safe sex always or regularly in both groups. However, around 50\% would never ask their partner to take an HIV test $(\chi 2$ $(3,409)=2.575 ; p=0.462)$. Only $5.3 \%$ and $8.9 \%$ of the subjects declared having ever an HIV test in cohort 1 and 2 respectively (U Mann Whitney $=20296.0 ; Z=-1.403 ; p=0.161)$. A low proportion of students reported having had a sexually transmitted disease $(2.1 \%$ and $4.5 \%$ in group 1 and 2 respectively; $\mathrm{U}$ Mann Whitney $=$ 20564.0; $Z=-1.302 ; p=0.193)$.
Differential and descriptive analysis by gender (hypothesis 2)

A detailed analysis of the univariate effects per gender revealed that females have a higher perceived invulnerability $(\mathrm{F}(1,371)=8.111$, $p=0.005 ; \eta^{2}=0.021$; see Figure 2$)$, but also maintained sexual relations more frequently $(\mathrm{F}$ $\left.(1,371)=8.211, p=0.004, \eta^{2}=0.021\right)$, used condoms with less frequency $(\mathrm{F}(1,371)=5.476$, $\left.p=0.02, \eta^{2}=0.014\right)$ and have fewer sexual partners throughout their lives than males $(\mathrm{F}$ (1, 371) $\left.=7.023, p=0.008 ; \eta^{2}=0.016\right)$.

\section{Figure 2}

Illusion of invulnerability to HIV/AIDS by gender

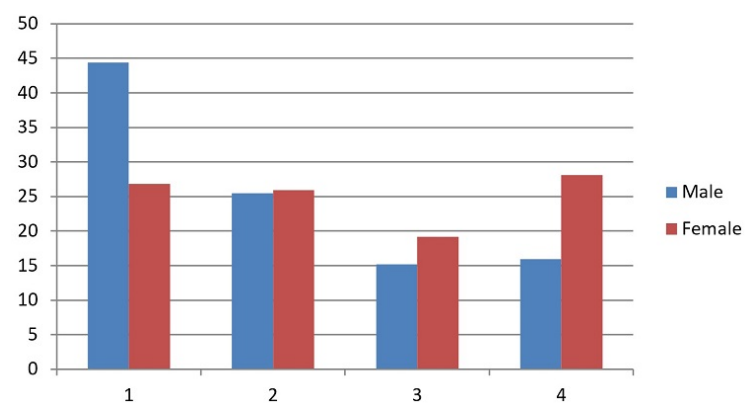

The descriptive analyses performed per gender revealed that whereas only $28 \%$ of males had sex every week and 26\% every month, 48\% of women said they practiced sex every week and $23 \%$ every month. Moreover, $39 \%$ of males reported having sex 1 to 5 times per year, but only $15 \%$ of females reported the same frequency (see Figure 3). Regarding the number of different sexual partners, $56 \%$ of males said they have had one or two in their life, $25 \%$ three or four and $19 \%$ five or more. On the other hand, $70 \%$ of women declared having had one or two different sexual partners, $16 \%$ three or four and $14 \%$ five or more (see Figure 4). With respect to the use of condoms, almost $92 \%$ of males and $85 \%$ of females stated that they used condoms always or habitually. About $11 \%$ of females and $2 \%$ of males said they had never used a condom (see Figure 5). Furthermore, 55\% of females and only $38 \%$ of males stated having a stable partner, 
with a statistically significant difference (U Mann Whitney $=19846.5 ; Z=-3.231 ; p=0.001)$.

Figure 3

Frequency of sexual relations by gender

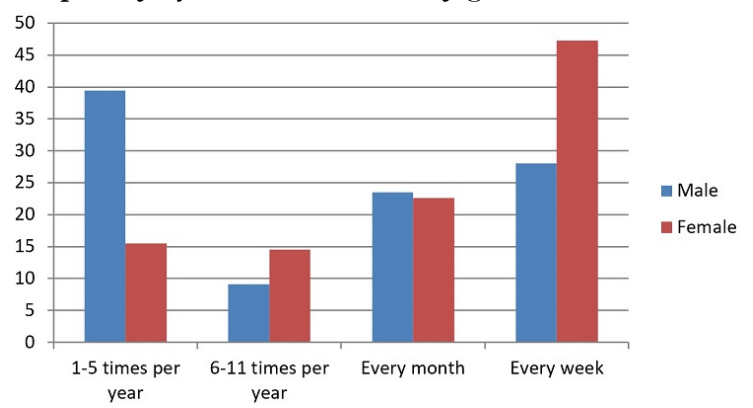

Figure 4

Number of sexual partners by gender

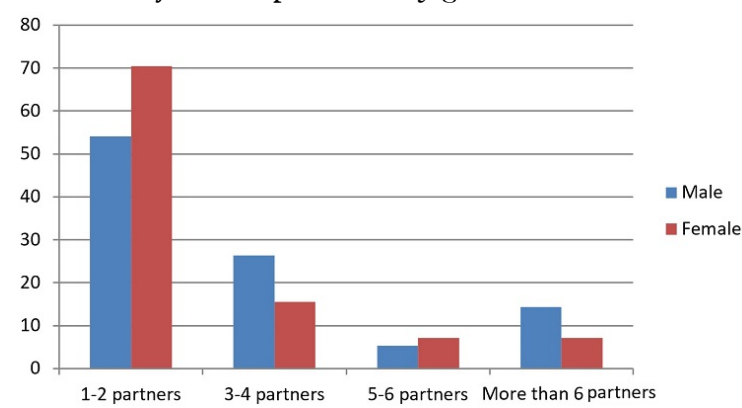

Figure 5

Frequency in the use of condoms by gender

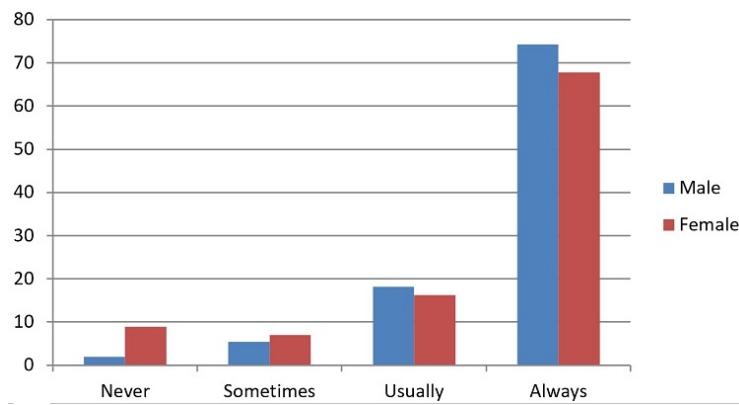

The vast majority of males and females used condoms in a situation of infidelity (99\% in both groups). More than half said they always or usually talked with their partner about safe sexual relations $(59 \%$ and $66 \%$ of males and females respectively). However, about half of both genders had never asked their partner to have the HIV test $\left(\chi^{2}(3,409)=0.995 ; p=\right.$ 0.812). Only $9 \%$ of males and $7 \%$ of females had ever had an HIV test (U Mann Whitney =
$17154.5 ; Z=-0.91 ; p=0.363)$ and also very few had contracted a sexually transmitted disease (less than $1 \%$ of males and around $5 \%$ of females; U Mann Whitney $=16964.5 ; Z=-1.856 ; p=$ 0.064).

Differential and descriptive analysis by having a stable partner or not (hypothesis 4)

Regarding the differences in sexual behaviour based on having a stable partner or not, the MANOVA analysis performed showed the existence of significant main effects (Wilks = 0.524; $F(6,383)=57.993 ; p<0.001 ; \eta^{2}=$ 0.48). Young people with a stable partner had sex more frequently $(\mathrm{F}(1,387)=237.19, p<$ $\left.0.001 ; \eta^{2}=0.44\right)$, had sex with fewer sexual partners during their sex lives $(\mathrm{F}(1,387)=10.26$ $\left.p=0.001 ; \eta^{2}=0.03\right)$, used condoms with less frequency $\left(\mathrm{F}(1,387)=14.78, p<0.001 ; \eta^{2}=\right.$ 0.04), spoke more with their partner about safe sexual relations $(\mathrm{F}(1,387)=3.77, p=0.02$; $\left.\eta^{2}=0.01\right)$, asked their partners less frequently to have an HIV test $(\mathrm{F}(1,387)=1.91, p=$ $\left.0.02 ; \eta^{2}=0.01\right)$ and perceived themselves more invulnerable to HIV/AIDS than young without a stable partner $(\mathrm{F}(1,387)=5.46, p=0.04$; $\eta^{2}=0.01$; see Figure 6$)$. Moreover, whether or not young people have a stable partner did not make significant differences in having had a sexually transmitted disease (U Mann Whitney $=20317.5 ; Z=-0.127 ; p=0.899)$, having ever had an HIV test (U Mann Whitney $=19879.5$; Z $=-0.910 ; p=0.363$ ) or condom use in situations of infidelity (U Mann Whitney $=20265.0 ; \mathrm{Z}=$ $-0.977 ; p=0.329)$. 
Figure 6

Illusion of invulnerability to HIV/AIDS by having or not a stable partner

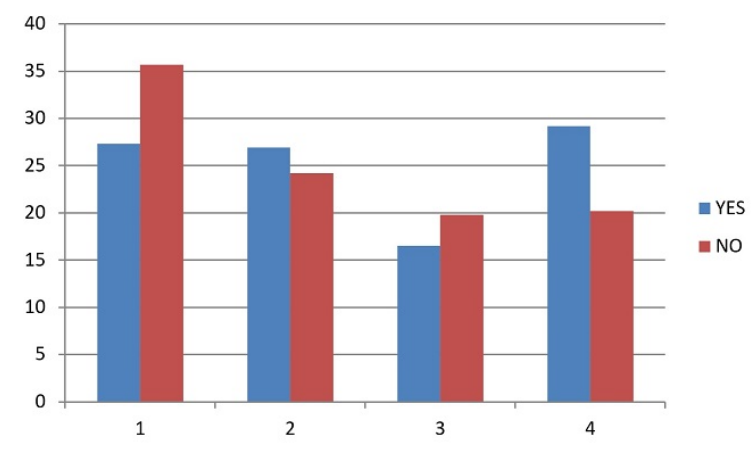

\section{Conclusions and discussion}

Our results showed that sexual behaviour and HIV/AIDS risk perception remained unchanged in two cohorts $(2004,2012)$ of Spanish university students studied 8 years apart. Broadly speaking, this result corroborated hypothesis 1 of our study, which we now examine in greater detail.

Most students in both groups reported being sexually active, having sex every week or every month, having on average 1-2 different sexual partners throughout their life, using condoms always or regularly, talking to their partner about safe sex regularly and almost all of them emphasized using condoms especially in situations of infidelity. However, half of the respondents stated that they were not capable of asking their partner to have an HIV test and less than ten percent ever having an HIV test in both groups. In line with the last point, a study of Spanish adolescents (16-20 years old) confirmed this trend of not having an HIV test, the major barriers being that no one recommended it, the low risk perception and confidence in their sexual partners (Morales, Espada \& Orgilés, 2016). Our data shows that Spanish university students are not especially promiscuous, contrary to what other studies have reported (Serrano et al., 2005).

Although our results are not alarming, it appears that young people assume some risk behaviour as normal and do not perceive it as risk at any time. For example, about one-fifth of sexually active young people used condoms regularly but not always and about one-sixth sometimes or never used them. Since they did not usually require their sexual partners to have an HIV test and did not have an HIV test themselves, they were assuming a real risk. These data confirm the trend of previous studies on inconsistent condom use and failure to test for HIV as the main behavioural risks assumed by Spanish young people (Bagmato et al., 2014; Ballester et al., 2009; Castro \& Santos-Iglesias, 2016). Given that statistics showed that about half of the infected people had a late diagnosis, these risk behaviours indicate that Spanish university students are exposed to HIV and other venereal diseases (HIV Surveillance and Risk Behaviour Area, 2018).

With respect to the illusion of invulnerability to HIV/AIDS, university students had rates close to $60 \%$ in 2004 and above $65 \%$ in 2012 . We could say that young people were guilty of overconfidence. The most concerning fact is that this situation remained unchanged in both cohorts studied. The only significant difference we found per cohort was an increase in the perception of invulnerability between 2004 and 2012, in the case of men, thus indicating an increase in overconfidence in males over time. A similar trend has been found in a previous study carried out in our country between 1999 and 2004 (Planes et al., 2005). This reaffirms the idea of a progressive increase in the illusion of invulnerability to HIV/AIDS over the years in Spain.

Our data contradicts the trend in the US towards young greater awareness and protection against HIV/AIDS over time (Teague, 2009) and is coherent with previous studies in our country (Lameiras et al., 2002; Planes et al., 2005; RojasMurcia et al., 2015; Ubillos et al., 2003). It should also be noted that the differences found in the American cohort study (Teague, 2009) may be due to the time period studied, spanning 15 years, with the first cohort evaluated at the start of the pandemic (1990). On the other hand, our study covered a shorter period (8 years) and both cohorts were evaluated when AIDS was well- 
known and considered chronic, but not a fatal disease.

With regard to gender differences (hypothesis 2), our data showed that young Spanish females perceived themselves more invulnerable to HIV/ AIDS, but also had sex more frequently, used condoms less frequently, had stable partners more frequently and had fewer sexual partners throughout their lives than males. Our data suggests that women are willing to assume more risk and confident, as they place their trust more in stable relationships. These gender differences in risk perception and sexual behaviour have been widely reported in literature (Lameiras et al., 2002; Larrañaga et al., 2012; Rojas-Murcia et al., 2015; Taiwo, 2015; Teva, Bermúdez \& Buela-Casal, 2009) and corroborate the second hypothesis of our study.

Our third hypothesis suggested the presence of small but significant differences by age. We assumed that between 18 and 25 years could increase the degree of awareness about the risk of AIDS and also protective sexual behaviours. However, our results did not support these differences, so hypothesis 3 would be rejected. The absence of preventative programs and policies on college campuses may explain this result.

With respect to the differences between having or not having a stable partner (hypothesis 4), our data showed that young people who have a stable partner assumed more risk in their sexual behaviour - since they practiced more sex, used condoms less frequently and also asked their partner to have an HIV test less frequently - thus feeling more invulnerable to HIV/AIDS than people without partner. These results confirmed our fourth hypothesis. This tendency to underestimate the risk of contracting HIV/AIDS when young people were in a stable relationship had been reported in previous studies (Aguilar \& Camargo, 2014; Lameiras et al., 2002; Planes et al., 2005). In support of our results, the study by Aguilar and Camargo (2014) showed that as the romantic relationship progressed, the illusion of invulnerability increased and condom use was replaced by other measures such as the pill to prevent pregnancy. This led to a greater lack of protection against venereal diseases. It also showed that the ideal of romantic love was positively related to a greater sense of invulnerability to HIV/AIDS (Aguilar \& Camargo, 2014).

Relying on our data, we can conclude that young people are not fully aware of the real risk they are facing with their sexual behaviour. It seems that a stable partner was perceived as a control and safety strategy against sexually transmitted diseases such as HIV/AIDS, leading to increased risk behaviour in such relationships and this was more evident in the case of females. The sexual history of their partners was not taken into account as a real risk. The couple was perceived as a relationship of trust and they were afraid to ask their partner to take an HIV test. Neither had they had an HIV test themselves; which implied that, if infected, they found out later with the increased risk of infecting others. Furthermore, although it seemed that they were aware of the risk relating to infidelity - claiming that they would take protective measures when they were directly involved in a situation of infidelity - however, they were confident and did not take these measures in the possibility of infidelity of their partner.

We should highlight the importance of ongoing preventive programs with young people in Spain, as the data shows that they are taking a real risk. HIV/AIDS prevention programs addressed to this population should be focused on raising awareness of the real risk they are taking and changing the perception of a stable partner as a strategy of protection against HIV/AIDS. Young people should distinguish between the relationship of trust of having a partner and safety against HIV/AIDS. Programs should convey the idea to young people that complete trust in each other -as a couple- also means being able to ask your partner to have an HIV test and also do it yourself. The ability to negotiate condom use or HIV testing with a partner can be two key components of prevention programmes. A previous study has shown that this ability was lower in the case of women and the greater the motivation for permanence in the relationship 
(Skakoon-Sparling \& Cramer, 2019). Since this trend was even more prevalent in the case of young women, it is essential to adopt a gender perspective in HIV/AIDS prevention programs (Larrañaga et al., 2012).

The limitations of this study include the small sample size and its cross-sectional and descriptive nature. However, additional cohort studies are required; either longitudinal or crosssectional, to study the changing trends in sexual and risk behaviour. This would enable an overall assessment of the extent to which intervention is producing major changes in the general population or not being very effective. Future studies should also be designed to further research the variables that may be influencing risk perception and sexual behaviour in young people. Although there have been many studies, most of them focus on the adolescent population and very few on young people (for example: Antón \& Espada, 2009; Espada et al., 2016; Morales et al., 2016). It is also recommended to extend the samples to non-university young people who are less accessible by surveys and who conceivably assume greater risks. A major deficiency in our context is to conduct studies that test the effectiveness of intervention intended to change behaviour that poses a risk of contracting HIV/AIDS and increase the awareness of the real risk assumed by young people with their sexual behaviour.

\section{Acknowledgements}

The collaboration of teachers who provided us with class time to administer questionnaires and anonymous students who decided to take part in our research is appreciated, as well as the institution that approved its implementation.

\section{References}

Aguilar, A., \& Camargo, B.V. (2014). Romantic relationships, adolescence and HIV: Love as an element of vulnerability. Paideia, 24(58), 165-175. https://doi.org/10.1590/1 $982-43272458201404$
Amare, T., Yeneabat, T., \& Amare, Y. (2019). A Systematic Review and Meta-Analysis of Epidemiology of Risky Sexual Behaviors in College and University Students in Ethiopia, 2018. Journal of Environmental and Public Health, 2019(4852130), 1-8.. https:// doi.org/10.1155/2019/4852130

Antón, F. A., \& Espada, J. P. (2009). Consumo de sustancias y conductas sexuales de riesgo para la transmisión del VIH en una muestra de estudiantes universitarios. Anales de Psicología, 25(2), 344-350. Retrieved from http://www.um.es/analesps/ v25/v25_2/17-25_2.pdf

Bagmato, M. J., Jenaro, C., Flores, N., \& Guzmán, K. (2014). Factores culturales asociados a las conductas sexuales en estudiantes universitarios de Uruguay y España: Estudio preliminar. Revista de la Facultad de Psicología, 4(1), 6-32. Retrieved from https://revista.psico.edu.uy/index.php /revpsicologia/article/view/176

Ballester, R., Gil, M. D., Giménez, C., \& Ruiz, E. (2009). Actitudes y conductas sexuales de riesgo para la Infección por $\mathrm{VIH} /$ Sida en jóvenes españoles. Revista de Psicopatología y Psicología Clínica, 14(3), 181-191. https://doi.org/10.5944/rppc.vol.1 4.num.3.2009.4077

Bisquerra, R. (1989). Introducción conceptual al análisis multivariante. Barcelona: Promociones y Publicaciones Universitarias.

Burger, J. M., \& Burns, L. (1988). The illusion of unique invulnerability and the use of effective contraception. Personality and Social Psychology Bulletin, 14(2), 264-270. h ttps://doi.org/10.1177/0146167288142005

Calatrava, M., López-Del Burgo, C., \& de Irala, J. (2012). Factores de riesgo relacionados con la salud sexual en los jóvenes europeos. Medicina Clínica, 138(12), 534-540. https:/ /doi.org/10.1016/j.medcli.2011.07.020

Castro, Á. \& Santos-Iglesias, P. (2016). Sexual behavior and sexual risks among Spanish university students: a descriptive study of gender and sexual orientation. Sexuality 
Research and Social Policy, 13(1), 84-94. htt ps://doi.org/10.1007/s13178-015-0210-0

Centers for Disease Control and Prevention (2017). HIV Surveillance Report: 2016, vol. 28. Retrieved from http://www.cdc.gov/hiv /library/reports/hiv-surveillance.html

Chávez, M., Petrzelová, J., \& Zapata, J. (2009). Actitudes respecto a la sexualidad en estudiantes universitarios. Enseñanza e Investigación en Psicología, 14(1), 137-151. Retrieved from http://www.redalyc.org/arti culo.oa?id=29214110

Cortés Alfaro, A., García Roche, R., \& Ochoa Soto, R. (2015). Comportamiento sexual y uso del condón en estudiantes de la facultad de tecnología de la salud. Revista Cubana de Medicina Tropical, 67(2), 202-212. Retrieved from https://www.medigraphic.com/pdfs/re vcubmedtro/cmt-2015/cmt152g.pdf

Espada, J. P., Morales, A., Guillén, A., Ballester, R., \& Orgilés, M. (2016). Predicting condom use in adolescents: a test of three socio-cognitive models using a structural equation modeling approach. BMC Public Health, 16(35). https://doi.org/10.1186/s12 889-016-2702-0

Failde, J. M., Lameiras, M., \& Bimbela, J. L. (2008). Prácticas sexuales de chicos y chicas españoles de 14-24 años de edad. Gaceta Sanitaria, 22 (6), 511-519. https://do i.org/10.1016/S0213-9111(08)75347-0

Fernández-Silva, C. A., \& Sánchez-Martínez, D. E. (2018). Actitudes y prácticas sexuales relacionadas con VIH/SIDA. Revista Salud UIS. 50(4), 352-359. https://doi.org/10.182 73/revsal.v50n4-2018008

Folasayo, A., Oluwasegun, A., Samsudin, S., Saudi, S., Osman, M., \& Hamat, R. (2017). Assessing the knowledge level, attitudes, risky behaviors and preventive practices on sexually transmitted diseases among university students as future healthcare providers in the central zone of Malaysia: a cross-sectional study. International Journal of Environmental Research and Public Health, 14(2), 1-14. https://doi.org/10.3390/ijerph1 4020159
Haile, Z., Kingori, C., Darlington, K. A., Basta, T., \& Chavan, B. (2017). HIV risk perception among college students at a university in the Midwest. Sexuality $\mathbb{E}$ Culture, 21 (1), 62-73. doi: https://doi.org/1 $0.1007 / s 12119-016-9380-z$

HIV Surveillance and Risk Behaviour Area. (2018). Vigilancia epidemiológica del VIH y sida en España 2017: Sistema de información sobre nuevos diagnósticos de VIH y Registro Nacional de Casos de Sida. Madrid: Plan Nacional sobre el Sida - S. G. de Promoción de la Salud y Epidemiología - ISCIII. Retrieved from https://www.mscbs.gob.es/ciudadanos /enfLesiones/enfTransmisibles/sida/vigilan cia/doc/InformeVIH_SIDA_2018_211120 18.pdf

Lameiras, M., Rodríguez, Y., \& Dafonte, S. (2002). Evolución de la percepción de riesgo de la trasmisión heterosexual del VIH en universitarios/as españoles/ as. Psicothema, 14(2), 255-261. Retrieved from http://www.psicothema.com/psicothe ma.asp?id $=717$

Larrañaga, E., Yubero, S., \& Yubero, M. (2012). Influencia del género y del sexo en las actitudes sexuales de estudiantes universitarios españoles. Summa Psicológica UST, 9(2), 5-13. https://doi.org/10.18774/4 48x.2012.9.89

Mavhandu-Mudzusi, A. H., \& Tesfay Asgedom, T. (2016). The prevalence of risky sexual behaviours amongst undergraduate students in Jigjiga University, Ethiopia. Health Sa Gesondheid, 21(1), 179-186. http s://doi.org/10.4102/hsag.v21i0.950

Morales, A., Espada, J. P., \& Orgilés, M. (2016). Barreras hacia la prueba de detección del VIH en adolescentes en España. Psychosocial Intervention, 25(3), 135-41. doi: https://doi.org/10.1016/j.psi.2016.06.002

Olubola, T. G. (2015). The role of gender and psychosocial factor on perceived vulnerability to HIV/AIDS infection among Young and middle-aged adults in Benin, Nigeria. Journal of Psychology $\mathbb{E}$ 
Psychotherapy, 5(2), 1-8. https://doi.org/10. 4172/2161-0487.1000175

ONUSIDA (2012). Informe sobre la epidemia mundial de Sida 2012. Retrieved from https:/ /www.unaids.org/sites/default/files/media_a sset/20121120_UNAIDS_Global_Report_ 2012_with_annexes_es_1.pdf

Othieno, C. J., Ōkoth, R., Peltzer, K., Pengpid, S., \& Malla, L. O. (2015). Risky HIV sexual behaviour and depression among University of Nairobi students. Annals of General Psychiatry, 14(16), 1-8. https://doi. org/10.1186/s12991-015-0054-2

Pastor, Y., Martínez-Zaragoza, F., Benavides, G., Solanes, A., \& Martín, B. (2008, september). Perceived invulnerability to AIDS in Spanish college students. Paper presented at 22th Conference of the European Health Psychology Society. Bath, Inglaterra. Abstract published on Psychology E Health, 23(1), 204.

Planes, M., Gómez, A. B., Gras, M. E., Font-Mayolas, S., Cunil, M., Aymerich, M., \& Soto, J. (2005). Cambios en las percepciones de riesgo frente al SIDA de los estudiantes universitarios durante la última década. Cuadernos de Medicina Psicosomática y Psiquiatría de Enlace, (76-77), 39-45. Retreived from http://dugi-doc.udg.edu/bitstream/ha ndle/10256/1177/Cuad-76-77-Trabajo4.pd $\mathrm{f}$ ? sequence $=1$

Rojas-Murcia, C., Pastor, Y., \& EstebanHernández, J. (2015). Ilusión de invulnerabilidad, estereotipos y percepción del control del SIDA en universitarios. Revista Iberoamericana de Psicología y Salud, 6(1), 28-38. https://doi.org/10.1016/ S2171-2069(15)70004-9

Sánchez, F., Rubio, J., Páez, D., \& Blanco, A. (1998). Optimismo ilusorio y percepción de riesgo. Boletín de Psicología, 58, 7-17. Retrieved from http://www.uv.es/seoane/bo letin/previos/N58-1.pdf

Serrano, I., Dueñas, J. L., Bermejo, R., Coll, C., Doval, J. L., Lete, I., ... Parrilla, J. J. (2005). Actividad sexual e información y uso de métodos anticonceptivos en la juventud española: resultados de una encuesta nacional. Progresos de Obstetricia y Ginecología, 48(6), 283-288. https://doi.org /10.1016/S0304-5013(05)72396-7

Skakoon-Sparling, S., \& Cramer, K. M. (2019). Are we blinded by desire? Relationship motivation and sexual risk-taking intentions during condom negotiation. The Journal of Sex Research. https://doi.org/10.1 080/00224499.2019.1579888

Taiwo, A. O. (2015). The role of gender and psychosocial factors on perceived vulnerability to HIV/AIDS infection among young and middle-aged adults in Benin City, Nigeria. Journal of Psychology $\mathbb{E}$ Psychotherapy, 5(2), 1-8. https://doi.org/10. 4172/2161-0487.1000175

Teague, S. M. (2009). Perceptions of vulnerability to HIV/AIDS: a comparison of two college cohorts, 1990 and 2005. AIDS Education and Prevention, 21 (6), 526-537. https://doi. org/10.1521/aeap.2009.21.6.526

Teva, I., Bermúdez, M. P., \& Buela-Casal, G. (2009). Variables sociodemográficas y conductas de riesgo para la infección por el VIH y las enfermedades de transmisión sexual (ETS) en adolescentes. España, 2007. Revista Española de Salud Pública, 83(2), 309-320. https://doi.org/10.1590/S1 $135-57272009000200013$

Thomas, T. L., Yarandi, H. N., Dalmida, S. G., Frados, A., \& Klienert, K. (2015). Cross-cultural differences and sexual risk behavior of emerging adults. Journal of Transcultural Nursing, 26(1), 64-72. https:// doi.org/10.1177/1043659614524791

Ubillos, S., Páez, D., Mayordomo, S., \& Sánchez, F. (2003). Sesgos cognitivos y explicaciones asociadas como factores determinantes de las conductas sexuales de riesgo. Revista de Psicología Social, 18(3), 261-279. https://doi .org/10.1174/021347403322470855

Weinstein, N. D. (1980). Unrealistic optimism about future life events. Journal of Personality and Social Psychology, 39(5), 806-820. https://doi.org/10.1037/0022-351 4.39.5.806 
Xu, H., Xie, J., Xiao, Z., Xiao, H., Li, X., Goldsamt, L., \& Wang, H. (2019). Sexual attitudes, sexual behaviors, and use of HIV prevention services among male undergraduate students in Hunan, China: a cross-sectional survey. BMC Public Health, 19(1). https://doi.org/10.1186/s12889-019. $6570-2$

\section{Notes}

* Research article. 